\title{
An Analysis of Dental Enamel after Bleaching using 35\% Hydrogen Peroxide with Energy-dispersive X-ray Spectroscopy
}

\author{
${ }^{1}$ Asmawati Amin, ${ }^{2}$ Bahruddin Thalib, ${ }^{3}$ Rafikah Hasyim, ${ }^{4}$ Ira Utami
}

\begin{abstract}
Introduction: Hydrogen peroxide $\left(\mathrm{H}_{2} \mathrm{O}_{2}\right)$ is an effective bleaching agent of tooth whitening, but its use causes changes in the chemical composition of the elements that configure tooth enamel. The purpose of this study is to determine whether there are changes in the composition of the elements that configure the tooth enamel after bleaching using $35 \% \mathrm{H}_{2} \mathrm{O}_{2}$.
\end{abstract}

Materials and methods: This study was performed in vitro, which is an experimental research laboratory with controlled time series design. The samples used in this study were six permanent incisors postextraction and are divided into treatment and control groups. The control group was soaked in saline and treatment groups applied with $\mathrm{H}_{2} \mathrm{O}_{2} 35 \%$, with time series of 1, 1.5, 2, 2.5, and 3 hours. The elemental composition of enamel was observed using energy-dispersive X-ray spectroscopy analysis; results can be obtained both qualitatively and quantitatively. This study was analyzed using non-parametric test (Kruskal-Wallis test) to determine changes in enamel composition after bleaching, whether there is a change in enamel composition or not.

Results: The results of this study showed a p-value of 0.406 $(p<0.05$; significant). The result shows a change in the composition of dental enamel after bleaching using $35 \% \mathrm{H}_{2} \mathrm{O}_{2}$.

Conclusion: Application of $35 \% \mathrm{H}_{2} \mathrm{O}_{2}$ as the bleaching agent does not have a significant influence on changes in the composition of the elements contained in the enamel.

Keywords: $35 \%$ hydrogen peroxide, Bleaching, Composition of dental enamel.

How to cite this article: Amin A, Thalib B, Hasyim R, Utami I. An Analysis of Dental Enamel after Bleaching using 35\% Hydrogen Peroxide with Energy-dispersive X-ray Spectroscopy. World J Dent 2017;8(5):393-397.

Source of support: Nil

Conflict of interest: None

\section{INTRODUCTION}

Enamel is the hardest tissue of teeth, which is the outer layer of the tooth crown. The thickness and density affect the surface of the tooth crown. The composition of

\footnotetext{
${ }^{1,3,4}$ Department of Oral Biology, Faculty of Dentistry, University of Hasanuddin, Makassar, Indonesia

${ }^{2}$ Department of Prosthodontics, Faculty of Dentistry, University of Hasanuddin, Makassar, Indonesia

Corresponding Author: Rafikah Hasyim, Department of Oral Biology, Faculty of Dentistry, University of Hasanuddin Makassar, Indonesia, e-mail: rafikahhasyim@gmail.com
}

elements of tooth enamel is composed of cells, organic matrix, and inorganic matrix; these cells control the initial production of tissue minerals. ${ }^{1}$ Tooth enamel consist of consist of $96 \%$ inorganic material, $4 \%$ water, organic matter, and fibrous tissue. Inorganic materials consisting of crystalline hydroxyapatite has the chemical formula $\mathrm{CA}_{10}\left(\mathrm{PO}_{4}\right)_{6}(\mathrm{OH})_{2}$. The content of the elements contained within tooth enamel is carbonate $(4 \%)$, sodium $(0.6 \%)$, magnesium $(1.2 \%)$, chloride $(0.2 \%)$, and a small amount of fluoride $(0.01 \%)$. The salts comprise of materials such as keratin (pseudokeratin), collagen, peptone, glycoproteins, polysaccharides, fats, and acids amino. ${ }^{2,3}$

Enamel consists of the outer and inner enamel, which are enamel surface and subsurface enamel. Surface enamel contains more fluorine and a little carbonate so that the surface enamel is harder, less porous, insoluble, and more radiopaque. ${ }^{4}$

Tooth discoloration is an esthetic complaint because it can affect a person's appearance. ${ }^{5}$ Tooth discoloration is influenced by a combination of intrinsic and extrinsic factors. The color change is extrinsic to the teeth caused by chromogens derived from the intake of food, tobacco, mouthwash, or plaque on the tooth surfaces, while the tooth discoloration is intrinsically caused by the stain deeper in the tooth enamel, which can be systemic factors, metabolism, genetic, and local. ${ }^{6,7}$

Tooth whitening (bleaching) is a method to remove stains on teeth. ${ }^{7}$ Bleaching is using for tooth whitening in the internal as well as external and for nonvital and vital teeth. External tooth whitening done on vital teeth changes color as a whole. Tooth whitening (bleaching) can be done in the clinic by the dentist directly or performed at home by the patients themselves or by monitoring of the dentist. External bleaching agent that is often used is $\mathrm{H}_{2} \mathrm{O}_{2}$ and carbamide peroxide. Both of these materials contain $\mathrm{H}_{2} \mathrm{O}_{2}$, which decomposes into $\mathrm{H}_{2} \mathrm{O}$ and $\mathrm{O}_{2}$. Materials used for teeth whitening carried out directly by the dentist contain peroxide with a high concentration (30-40\%), while active ingredients applied for use at home by the patient using materials that are sold freely or under the supervision of a dentist have a lower concentration of carbamide peroxide (10-20\%) and $\mathrm{H}_{2} \mathrm{O}_{2}(3-7.5 \%)$. ${ }^{8,9}$ 
Hydrogen peroxide is known as dihydrogen dioxide, hydrogen dioxide, oxydol, and peroxide, the chemical formula is $\mathrm{H}_{2} \mathrm{O}_{2}, \mathrm{pH} 4.5$, which is a clear, colorless, and odorless liquid, with a molecular weight of $34.0147 \mathrm{gm} / \mathrm{mol}$ and is more viscous than water. ${ }^{10}$ Hydrogen peroxide as a bleaching agent is effective in tooth whitening, but there are some concerns on the use of this material, which has been reported in some studies; complications after tooth whitening (postbleaching) include changes in the surface morphology of the enamel and dentin, changes in chemical composition, increased permeability, and mechanical changes. Hydrogen peroxide as a bleaching agent of tooth whitening is safe to use when used in a controlled concentration, usage time is not too long (when used in high concentration) and within a certain time interval. $^{8}$

The purpose of this study was to analyze the compound of dental enamel after bleaching using 35\% $\mathrm{H}_{2} \mathrm{O}_{2}$.

\section{MATERIALS AND METHODS}

This study is an experimental research with controlled time series design. This study was conducted at the Laboratory of Oral Biology, Faculty of Dentistry, Hasanuddin University and at the Laboratory of Microstructure Physics, State University of Makassar. This study uses $\mathrm{H}_{2} \mathrm{O}_{2}$ for bleaching and insisvus permanent with This study uses $\mathrm{H}_{2} \mathrm{O}_{2}$ for permanent incisors. Six samples were used in this study. The control group consisted of one sample and treatment group consisted of five samples. Permanent caries-free incisor tooth was stain cleaned and stored in saline solution $(0.9 \% \mathrm{NaCl})$. Teeth were cut $1 / 2$ length of the roots and crowns were clipped sagittal with a size of $3 \mathrm{~mm}$ using a carborundum disc. Five samples treated by time series at the same time was applied with bleaching material $\mathrm{H}_{2} \mathrm{O}_{2}$. In the control

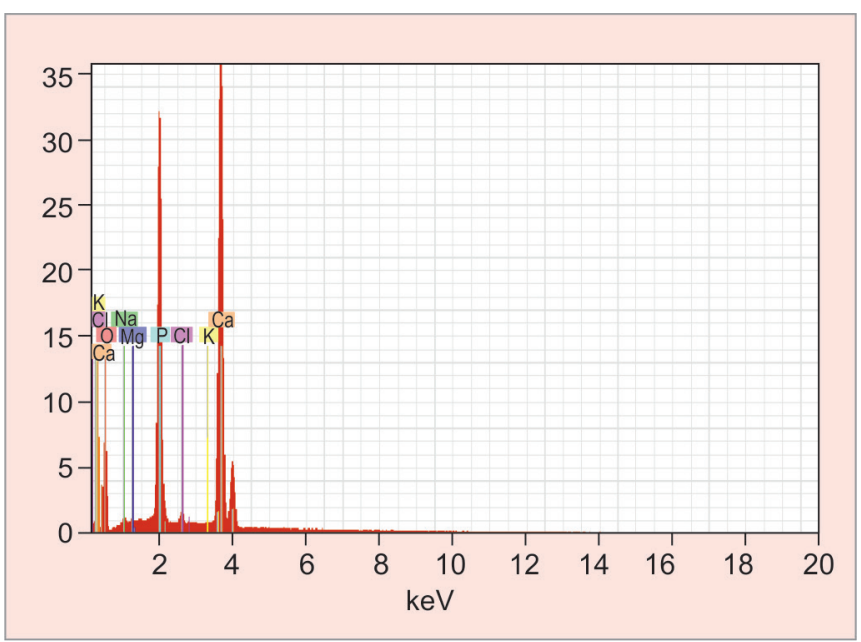

Graph 1: X-ray diffraction pattern of the enamel (control) soaked with a solution of saline for 24 hours
Table 1: Composition of dental enamel with EDS

\begin{tabular}{llll}
\hline \multirow{2}{*}{$\begin{array}{llll}\text { Enamel } \\
\text { composition }\end{array}$} & EDS & Normal test & $\begin{array}{l}\text { Comparative } \\
\text { test }\end{array}$ \\
\cline { 2 - 4 } Mean $\pm S D$ & $14.0483 \pm 1.01873$ & $0.167^{*}$ & 0.406 \\
\hline Oxygen & $0.3450 \pm 0.11845$ & $0.676^{*}$ & \\
Codium & $3.2533 \pm 0.21172$ & $0.702^{*}$ & \\
Phosphom & $1.3850 \pm 0.26599$ & $0.054^{*}$ & \\
Potassium & $0.1433 \pm 0.01366$ & $0.093^{*}$ & \\
Chlorine & $0.1417 \pm 0.01169$ & 0.033 & \\
Magnesium & $0.1317 \pm 0.04070$ & $0.295^{*}$ & \\
\hline
\end{tabular}

*Shapiro-Wilk test: $p>0.05$; normal distribution, ${ }^{* *}$ Kruskal-Wallis test: $p<0.05$; significant; SD: Standard deviation

group, samples were stored in saline solution and the treated samples were applied with $35 \% \mathrm{H}_{2} \mathrm{O}_{2}$ for 1, 1.5, $2,2.5$, and 3 hours. After application of each sample, it is cleaned using distilled water and then dried. After drying, the sample was analyzed using energy-dispersive X-ray spectroscopy (EDS). ${ }^{11}$

\section{RESULTS}

Observations of dental enamel using EDS show results in the form of graphs. The graphs consists of control charts, treatment charts with $35 \% \mathrm{H}_{2} \mathrm{O}_{2}$ bleaching for 1 hour, 1 hour 30 minutes, 2 hours, 2 hour 30 minutes and 3 hours (Graphs 1 to 6).

The analysis of nonparametric test (Kruskal-Wallis test) gives a p-value of 4 (the null hypothesis), which means there is no difference. This means that there is no significant difference in the composition of the enamel between the control group and the group that received treatment with $35 \% \mathrm{H}_{2} \mathrm{O}_{2}$.

Table 1 shows analysis of nonparametric test (Kruskal-Wallis test); it can be seen that the average oxygen composition of each treatment was 14.0483, the average composition of sodium from each treatment was

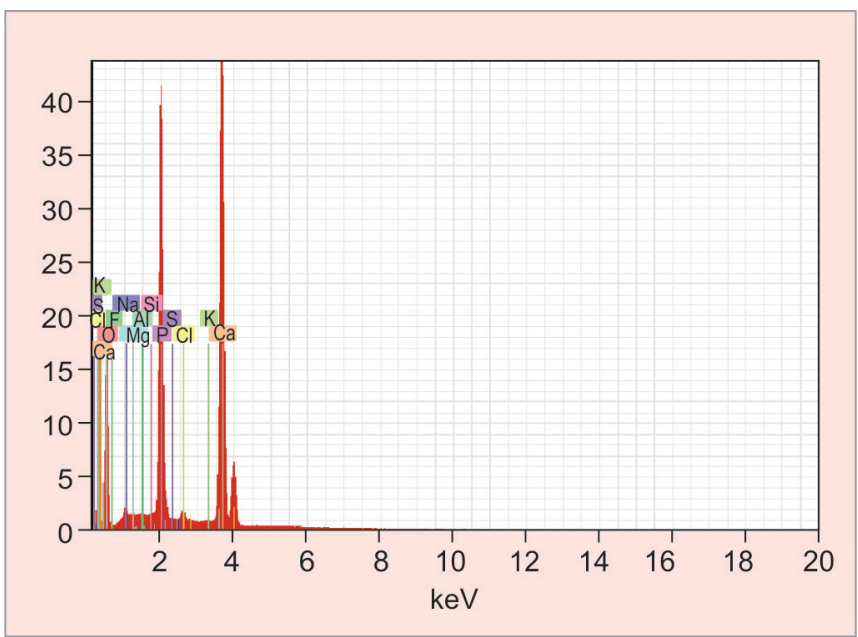

Graph 2: X-ray diffraction pattern of the tooth enamel bleached using $35 \% \mathrm{H}_{2} \mathrm{O}_{2}$ for 1 hour 


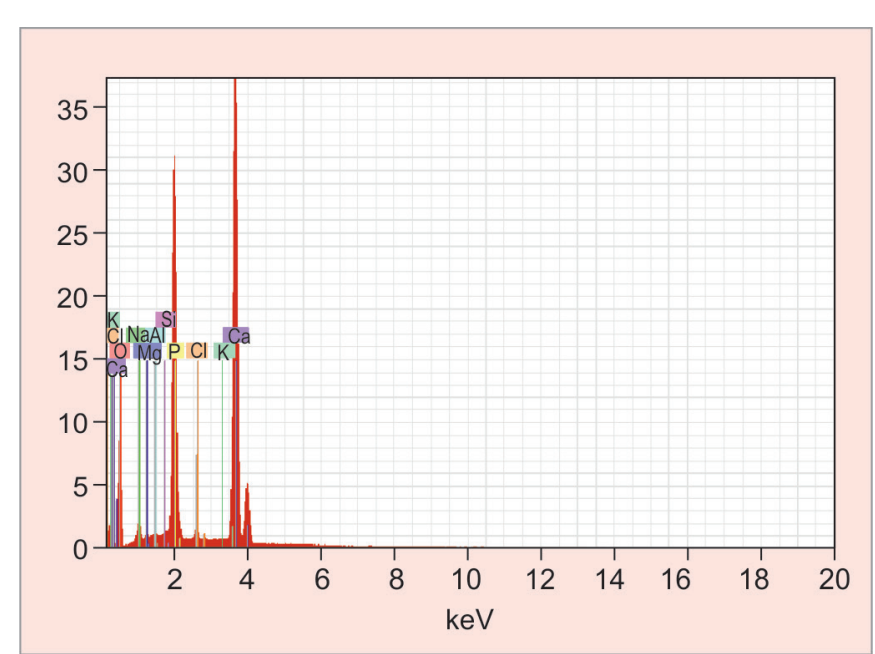

Graph 3: X-ray diffraction pattern of the tooth enamel bleached using $35 \% \mathrm{H}_{2} \mathrm{O}_{2}$ for 1.5 hours

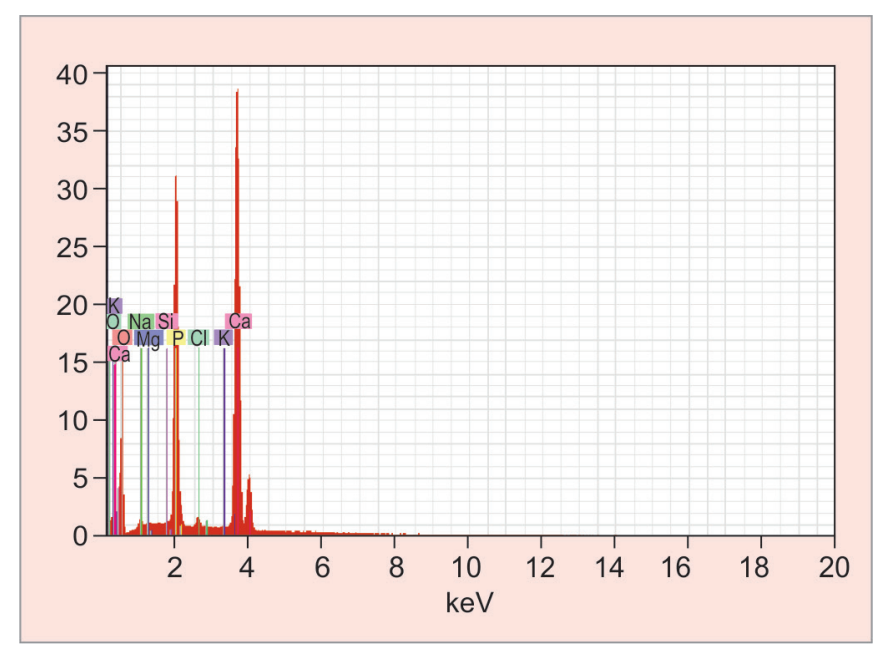

Graph 5: X-ray diffraction pattern of the tooth enamel bleached using $35 \% \mathrm{H}_{2} \mathrm{O}_{2}$ for 2.5 hours

0.3450, the average composition of calcium from each treatment was 3.2533 , the average phosphorus composition of each treatment was 1.8850 , the average composition of potassium from each treatment was 0.1433 , the average composition of the chlorine from each treatment was 0.1417 , the average composition of magnesium of any treatment was 0.1317 . Statistical test results obtained the value of $p=0.406>0.05$, which means Ho (the null hypothesis) is received, which means there is no effect. This means that "the treatment of $\mathrm{H}_{2} \mathrm{O}_{2}$ as a dental bleaching agent does not have a significant influence on the enamel surface of the tooth".

Table 1 shows analysis of non parametric test (Kruskal-Wallis test), which appears that the value of $\mathrm{p}=0.406>0.05$ which means that Ho (the null hypothesis) is received, which means there is no difference. This means that "there is no significant difference in the composition of the enamel between the control group and the group receiving treatment hydrogen applications".

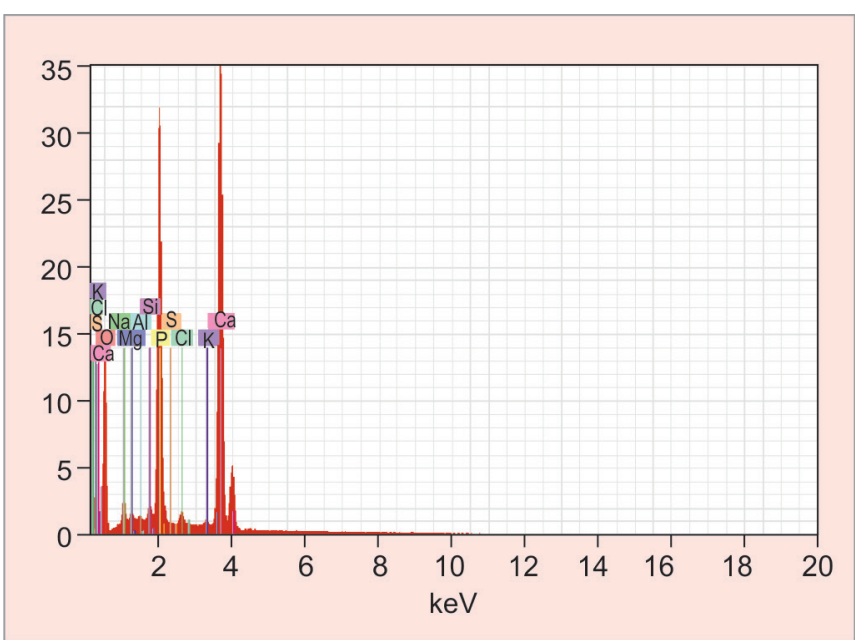

Graph 4: X-ray diffraction pattern of the tooth enamel bleached using $35 \% \mathrm{H}_{2} \mathrm{O}_{2}$ for 2 hours

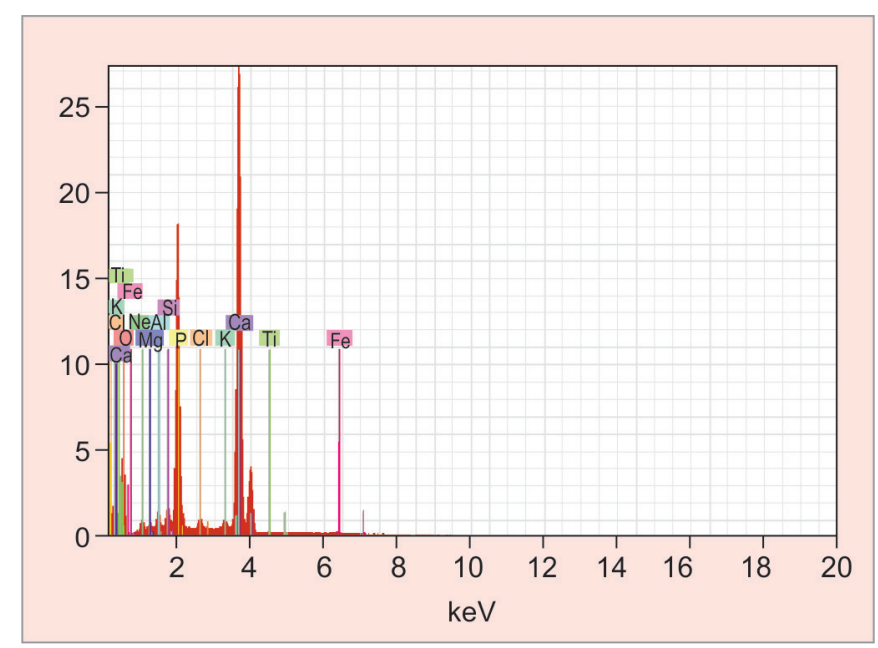

Graph 6: X-ray diffraction pattern of the tooth enamel bleached using $35 \% \mathrm{H}_{2} \mathrm{O}_{2}$ for 3 hours

Table 2 shows enamel composition from the EDS. Based on the Kruskal-Wallis test results, obtained $p=0.406$ ( $p<0.05$; significant). This means there are no significant differences in the composition of the enamel between the control group and the group receiving treatment with $\mathrm{H}_{2} \mathrm{O}_{2}$.

\section{DISCUSSION}

The purpose of this study was to analyze the content of the elements contained in the enamel after bleaching using $35 \% \mathrm{H}_{2} \mathrm{O}_{2}$. This research was carried out in vitro; there is a difference between in vitro and oral cavity situation. There is saliva in the oral cavity that can inhibit the demineralization because it contains calcium and phosphate. Saliva also has the effect to neutralize the oral $\mathrm{pH}$ (buffer capacity of saliva). ${ }^{12}$

In this study, control and treatment samples were soaked with saline solution. Saline solution has a neutral $\mathrm{pH}$, which is expected to minimize the effect of the 
Table 2: Differences in the composition of the enamel between the control group and the group receiving treatment with $\mathrm{H}_{2} \mathrm{O}_{2}$

\begin{tabular}{|c|c|c|c|c|c|c|c|c|c|}
\hline & & & & & & & & $\begin{array}{l}\text { Normality } \\
\text { test }\end{array}$ & $\begin{array}{l}\text { Comparison } \\
\text { test }\end{array}$ \\
\hline Enamel composition & Oxygen & Sodium & Calcium & Phosphorus & Potassium & Chlorine & Magnesium & $p$-value & $p$-value \\
\hline Control & 15.11 & 0.22 & 3.49 & 2.02 & 0.13 & 0.15 & 0.11 & $0.001^{*}$ & $0.406^{\star *}$ \\
\hline $\mathrm{H}_{2} \mathrm{O}_{2} 1$ hour & 14.52 & 0.35 & 3.35 & 2.13 & 0.13 & 0.15 & 0.16 & & \\
\hline $\mathrm{H}_{2} \mathrm{O}_{2} 1.5$ hours & 13.95 & 0.53 & 3.13 & 1.94 & 0.16 & 0.15 & 0.20 & & \\
\hline $\mathrm{H}_{2} \mathrm{O}_{2} 2$ hours & 14.09 & 0.43 & 3.26 & 1.88 & 0.14 & 0.14 & 0.11 & & \\
\hline $\mathrm{H}_{2} \mathrm{O}_{2} 2.5$ hours & 14.48 & 0.30 & 3.39 & 1.97 & 0.14 & 0.14 & 0.12 & & \\
\hline $\mathrm{H}_{2} \mathrm{O}_{2} 3$ hours & 12.14 & 0.24 & 2.90 & 1.37 & 0.16 & 0.12 & 0.09 & & \\
\hline
\end{tabular}

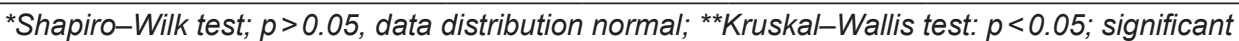

results of the study. The results of this study show that the elements can be detected, which are oxygen $(\mathrm{O})$, sodium $(\mathrm{Na})$, magnesium $(\mathrm{Mg})$, phosphorus $(\mathrm{P})$, calcium $(\mathrm{Ca})$, potassium $(\mathrm{K})$, and chlorine $(\mathrm{CR})$, contained in dental enamel. ${ }^{1}$ This shows that research using EDS can be used to analyze qualitatively. The EDS is an ideal system to present all the data of X-ray of a specimen and qualitative analysis could be done both qualitatively and quantitatively. ${ }^{13}$

Calcium is a major component in the structure of the tooth, and enamel demineralization occurs due to release of calcium ions from the tooth enamel; the effect of acid on tooth enamel is a decomposition reaction. ${ }^{14}$

The duration or length of the teeth in contact with the material bleaching affects the demineralization process; the number of elements of tooth enamel is not only influenced by the degree of acidity $(\mathrm{pH})$ and the concentration of the bleaching but the length of time or duration of $\mathrm{H}_{2} \mathrm{O}_{2}$ in contact with the teeth can also affect the levels of dissolution of the content mineral of dental enamel. ${ }^{15}$

The EDS analysis results showed that the average oxygen composition of each treatment was 14.0483, the average composition of sodium from each treatment was 0.3450 , the average composition of calcium from each treatment was 3.2533, the average composition of phosphorus from each treatment was 1.8850, the average composition of potassium from each treatment was 0.1433 , the average composition of chlorine from each treatment was 0.1417 , the average composition of magnesium of any treatment is 0.1317. Statistical analysis was performed with Kruskal-Wallis test, and no results are visible and do not have a statistically significant difference between the control and treatment of bleaching.

Tezel et $\mathrm{al}^{15}$ reported that the bleaching agent with a particular concentration showed a significant result in the loss of calcium from the surface enamel, but Goo et $\mathrm{al}^{16}$ reported that mineral loss caused by bleaching is not a big problem in the tooth.

Research conducted by Kazia et $\mathrm{al}^{12}$ using bleaching ingredients with a neutral $\mathrm{pH}$ using analytical scanning electron microscope and EDS microanalysis showed no visible difference in the results, which are statistically significant between treatment and control groups. Lee et $\mathrm{al}^{17}$ also reported on the amount of calcium lost from teeth bleaching treatment after 12 hours together with calcium lost from teeth caused by consuming a soft drink or juice for a few minutes. This study concludes that changes in chemical composition on tooth enamel are small and not clinically significant. ${ }^{18}$

\section{CONCLUSION}

The $35 \% \mathrm{H}_{2} \mathrm{O}_{2}$ as the bleaching agent does not have a significant influence on changes in the composition of the elements contained in the enamel.

\section{REFERENCES}

1. Fauziah E, Suwelo IS, Soenawan H. The content of fluoride element in the enamel which is cured by glass and compomer ionomer. Indones J Dent 2008;15(3):205-211.

2. Mihu CM, Dudea D, Melincovici C, Bocşa B. Tooth enamel, the result of the relationship between matrix proteins and hydroxyapatite crystals. Appl Med Inf 2008;23(3-4):68-72.

3. Pizani AM, Tholt B, Paciornik S, Dias KR, de Albuquerque PP, Queiroz CS. Dental bleaching agents with calcium and their effects on enamel microhardness and morphology. Braz J Oral Sci 2015 Apr-Jun;14(2):154-158.

4. Berkovitz, BK.; Moxham, BJ.; Linden, RW. Master dentistry. Vol 3. London: Elvesier; 2011. p. 142-147.

5. Brinda B, Madan Kumar PD, Junaid M. Effect of an indigenously available herbal tooth whitening system on human enamel microhardness and micromorphology-an in-vitro study. Sch J Dent Sci 2015 Jun-Jul;2(3A):254-258.

6. Al-Qahtani MQ. Tooth bleaching procedures and their controversial effect: a literature review. Saudi Dent J 2014 Apr;26(2):36-38.

7. Dudea D, Florea A, Mihu C, Câmpeanu R, Nicola C, Benga G. The use of scanning electron microscopy in evaluating the effect of a bleaching agent on the enamel surface. Rom J Morphol Embryol 2009 Feb;50(3):435-440.

8. Berger SB, Soares LES, Martin AA, Ambrosano GMB, Tabchoury CPM, Giannini M. Effects of various hydrogen peroxide bleaching concentrations and numbers of application on enamel. Braz J Oral Sci 2014 Jan-Mar;1(13):22-27.

9. Suprastiwi E. The use of carbamide peroxide as a tooth whitener. Indones J Dent 2005;12(3):139-145. 
10. European Commission Health \& Consumer Protection Directorate-General. Hydrogen peroxide in tooth whitening products. SCCP; 2004. p. 1-8.

11. Justino LM, Tames DR, Demarco FF. In situ and in vitro effects of bleaching with carbamide peroxide on human enamel. Oper Dent 2004 Mar-Apr;29(2):219-225.

12. Kazia N, Suvarna N, Shetty HK, Kumar P. Effect of bleaching agents having a neutral $\mathrm{pH}$ on the surface of mineral trioxide aggregate using electron microscopy and energy dispersive X-ray microanalysis. J Conserv Dent 2016 Sep-Oct;19(5):428-433.

13. Sabel N. Enamel of primary teeth-morphological and chemical aspects. Swed Dent J Suppl 2012;222:1-77.

14. Panigoro S, Damajanty P, Juliatri HC. Levels of dissolved tooth calcium in soaking isotonic drinks. Journal of e-GiGi (eG) 2015 Jul-Dec;3(2):356-360.
15. Tezel H, Ertas OS, Ozata F, Dalgar H, Korkut ZO. Effect of bleaching agents on calcium loss from the enamel surface. Quintessence Int 2007 Apr;38(4):339-347.

16. Goo DH, Kwon TY, Nam SH, Kim HJ, Kim KH, Kim YJ. The efficiency of $10 \%$ carbamide peroxide gel on dental enamel. Dent Mater J 2004 Dec;23(4):522-527.

17. Lee KH, Kim HI, Kim KH, Kwon YH. Mineral loss from bovine enamel by a $30 \%$ hydrogen peroxide solution. J Oral Rehabil 2006 Mar;33(3):229-233.

18. Sasaki RT, Arcanjo AJ, Flório FM, Basting RT. Micromorphology and microhardness of enamel after treatment with homeuse bleaching agents containing 10\% carbamide peroxide and 7.5\% hydrogen peroxide. J Appl Oral Sci 2009 Nov-Dec; 17(6):611-616. 